\title{
Effects of leptin on human breast cancer cell lines in relationship to estrogen receptor and HER2 status
}

\author{
AMITABHA RAY, KATAI J. NKHATA and MARGOT P. CLEARY
}

\author{
Hormel Institute, University of Minnesota, 801 16th Avenue NE, Austin, MN 55912, USA
}

Received February 1, 2007; Accepted March 20, 2007

\begin{abstract}
Obesity is a risk factor for postmenopausal breast cancer and is associated with poor prognosis. Leptin, a cytokine synthesized in adipose tissue, has been implicated as a link between obesity and breast cancer. In the present study, the effects of leptin on cell proliferation and proteins associated with leptin signaling and/or breast cell growth were investigated in ER-positive, MCF-7, T47-D and MDA-MB-361, and ERnegative, MDA-MB-231 and SK-BR-3, breast cancer cell lines. MDA-MB-361 and SK-BR-3 also overexpress HER2/neu. For proliferation assays, 96-well plates were used and for protein determinations cells were synchronized in 6-well plates for 18-24 $\mathrm{h}$ in serum-free medium. Leptin was added at 0,5 , $10,25,50$ and $100 \mathrm{ng} / \mathrm{ml}$ for 24 and $48 \mathrm{~h}$. For Western blot analyses, protein extracts were probed for Ob-Rb, Ob-R, leptin, Jak2, PI3K, Stat3, p-Stat3, PCNA, cyclin D1, Cox-2, VEGF, Bcl-2, Bcl- $x_{\mathrm{L}}$, Bax, insulin, IGF-I, IGFBP3, IGF-IR $\alpha$, aromatase, CYP1A1 and CYP1B1. Overall, except for MCF-7 cells, leptin stimulated proliferation in all lines. MCF-7 cells expressed higher levels of Ob-Rb, Jak2, PI3K, Stat 3 and p-Stat3 in a dose-dependent manner to $50 \mathrm{ng} / \mathrm{ml}$ at $24 \mathrm{~h}$; and IGF-IR $\alpha$ increased at $24 \mathrm{~h}$. Cyclin D1 and Cox-2 levels increased with leptin treatment. Higher CYP1B1 expression was observed at both 24 and $48 \mathrm{~h}$. In MDA-MB-231 cells, p-Stat3 and Bcl- $\mathrm{x}_{\mathrm{L}}$ were increased at $48 \mathrm{~h}$; whereas PCNA and cyclin D1 expression increased in leptin-treated cells at 24 and $48 \mathrm{~h}$. In T47-D cells, Jak2 and Stat 3 were elevated at higher leptin concentrations at 24 and $48 \mathrm{~h}$. However, p-Stat 3 and PCNA demonstrated an increase only in 48-h leptin-treated cells. Furthermore, cyclin D1 exhibited higher expression at both 24 and $48 \mathrm{~h}$, while $\mathrm{Bcl}-\mathrm{x}_{\mathrm{L}}$ expression was lower with increasing concentrations of leptin at $48 \mathrm{~h}$. In MDA-MB-361 cells, Ob-Rb and VEGF increased at 24 and $48 \mathrm{~h}$; whereas PI3K, Stat3, PCNA and insulin levels increased in leptin-treated MDA-
\end{abstract}

Correspondence to: Dr Margot P. Cleary, Hormel Institute, University of Minnesota, 801 16th Avenue NE, Austin, MN 55912, USA

E-mail: mpcleary@hi.umn.edu

Key words: leptin, breast cancer, cell lines, leptin receptor
MB-361 cells after $48 \mathrm{~h}$. Bcl-2 and IGF-IR $\alpha$ were decreased at $24 \mathrm{~h}$ and a dose-dependent increase at $48 \mathrm{~h}$ was noted. Higher expression of CYP1B1 was observed with leptin for $24 \mathrm{~h}$. In SK-BR-3 cells, Ob-R increased at both 24 and $48 \mathrm{~h}$. A similar trend was found for IGF-I and IGFBP3 expression. Higher levels of Jak2 and PI3K were observed after $24 \mathrm{~h}$. Interestingly, there was a gradual increase of leptin expression at $24 \mathrm{~h}$, but a gradual decrease at $48 \mathrm{~h}$ in relation to the dose of leptin. In contrast, PCNA and IGF-IR $\alpha$ showed a decline at $24 \mathrm{~h}$ and an increase at $48 \mathrm{~h}$. Elevated levels of cyclin D1, VEGF and Bax were detected at $48 \mathrm{~h}$ in cells and increased Cox -2 expression was observed at $24 \mathrm{~h}$. These data indicate that leptin may influence breast cancer development in relation to ER status as well as to the presence or absence of HER2. Continued study on leptin may be helpful for a better understanding of breast cancer development in obese women.

\section{Introduction}

Obesity is an important risk factor for breast cancer among postmenopausal women $(1,2)$. Furthermore, obesity is associated with a poorer prognosis in both premenopausal and postmenopausal breast cancer patients $(3,4)$. Additionally diet-induced and genetic obesities have been reported to shorten latency and/or increase incidence for transgenic and carcinogen-induced mammary tumors $(5,6)$.

To explain the connection between postmenopausal obesity and breast cancer, various mechanisms have been suggested, which include increased biosynthesis of estrogens by adipose tissue aromatase (CYP19) and higher levels of insulin and insulin-like growth factors (IGFs) in association with the metabolic syndrome $(7,8)$. Obviously, estrogens play a pivotal role in breast cancer probably by stimulating cellular proliferation and oxidative metabolism mediated by various cytochrome P450 (CYP) enzymes such as CYP1A1 and CYP1B1 (9). The function of estrogens is also associated with insulin $(10,11)$, which increases the activity of IGF-I by enhancing its synthesis and by decreasing its binding proteins (IGFBPs). The metabolic signals induced by either insulin or IGF-I can promote tumor development (12). In fact, the IGF family, composed of ligands, receptors and binding proteins, is important in overall tissue homeostasis (10).

Body weight and/or body fat is closely related with circulating leptin concentrations $(13,14)$. Thus, obesity is characterized by elevated leptin levels (15). Leptin is a protein with cytokine-like activity, secreted mainly by adipocytes, and 
is thought to play an important role in the control of satiety, energy expenditure, food intake, and various reproductionrelated functions $(16,17)$. Leptin exerts its physiological functions through the leptin receptor $(\mathrm{Ob}-\mathrm{R})$, which has at least 6 alternatively spliced forms (Ob-Ra to Ob-Rf) with modifications mainly at the $\mathrm{C}$-terminus; $\mathrm{Ob}$ - $\mathrm{Rb}$, the long form of the leptin receptor, appears to be important for leptin's weight regulating effects. Leptin predominantly activates the Janus kinase (Jak)/signal transducer and activator of transcription (Stat) signal transduction pathway (18). The activation of Ob-Rb leads to Jak2 phosphorylation, which can then recruit Stat3 (tyrosine-phosphorylated), finally leading to nuclear translocation and stimulation of transcription $(18,19)$. Further, leptin regulates a well-known insulin target, phosphatidylinositol 3-kinase (PI3K), this phenomenon perhaps indicating cross-talk between the leptin and insulin signaling pathways (20).

It has been suggested that leptin enhances aromatase activity (21), which is involved in the aromatization of androgen into estrogen and linked with postmenopausal breast cancer risk. However, there may be other potential pathways of interaction between leptin and estrogen activity. Several studies have proposed the involvement of leptin in the pathological process of breast cancer (22-24). For example, the leptin receptor $(\mathrm{Ob}-\mathrm{Rb})$ has been identified in breast tumor samples and in human breast cancer cell lines; and in addition, leptin has been shown to stimulate cell proliferation and tumor progression (25-27). Leptin has been reported to increase the expression of cyclin D1 in human breast cancer cells and vascular endothelial growth factor (VEGF) in mouse mammary cancer cells, probably through PI3K and/or Jak2/ Stat 3 signaling pathways $(28,29)$, which are also associated with leptin signaling. Moreover, an association between Stat3 and the transcriptional regulation of human cyclin D1 has been demonstrated in breast cancer cells (30). Hsieh et al (31) observed elevated levels of phosphorylated Stat3 (p-Stat3) in invasive breast cancer tissues compared to normal breast tissue, and association of $\mathrm{p}$-Stat 3 with metastasis in regional lymph nodes. Their study also revealed that $\mathrm{p}$-Stat 3 levels were significantly associated with anti-apoptotic markers, VEGF and cyclooxygenase 2 (Cox-2), in invasive breast cancer tissues (31).

The aim of the present study was to expand the investigation of the in vitro effects of leptin concentration on cell proliferation and on proteins important in leptin signaling including leptin receptors (Ob-Rb and Ob-R) and Jak2, PI3K, Stat3, and p-Stat 3 in estrogen receptor-positive MCF-7, T47-D and MDA-MB-361 and estrogen receptor-negative MDA-MB-231 and SK-BR-3 human breast cancer cell lines (MDA-MB-361 and SK-BR-3 are positive for HER2/neu, whereas others are negative). In addition, cell proliferation/tumor progression markers, e.g., proliferating cell nuclear antigen (PCNA), cyclin D1, Cox-2 and VEGF; and insulin and related parameters, e.g., IGF-I, IGFBP3, IGF-I receptor $\alpha$ (IGF-IR $\alpha$ ), were determined. Also, Western blot analyses were performed to evaluate antiapoptotic markers Bcl-2 and Bcl- $\mathrm{x}_{\mathrm{L}}$, pro-apoptotic marker Bax, aromatase (CYP19), CYP1A1 and CYP1B1 in the abovementioned human breast cancer cell lines. Furthermore, the presence of leptin receptors was detected immunocytochemically in these cell lines.

\section{Materials and methods}

Cell culture. The following procedures were applied to all assays (i.e., cell proliferation, immunocytochemistry and the Western blot analyses). Estrogen-dependent breast cancer cell lines MCF-7, T47-D and MDA-MB-361, and estrogenindependent cell lines MDA-MB-231 and SK-BR-3 were cultured in serum-free medium for $18 \mathrm{~h}$. For MCF-7 and T47-D, Eagle's minimum essential medium [American Type Culture Collection (ATCC), Manassas, VA] and RPMI-1640 (Mediatech, Herndon, VA) were used, respectively. Leibovitz's L-15 medium (ATCC) was used for MDA-MB-361 and MDA-MB-231. McCoy's 5A medium (ATCC) was used for SK-BR-3. All cell lines were purchased from ATCC. Then, along with the control (without any treatment), the following concentrations of leptin were added to the respective wells: $5,10,25,50$ and $100 \mathrm{ng} / \mathrm{ml}$. The cells were incubated with leptin for 24 and $48 \mathrm{~h}$.

Cell proliferation assay. All cells were cultured in T-75 culture flasks, up to $70-90 \%$ confluency. Cells were harvested and counted, and plated at 5000 cells per well in 96-well plates overnight. Afterwards, cells were grown in serum-free medium for $18 \mathrm{~h}$, leptin was added according to the above-mentioned concentrations and incubated for 24 and $48 \mathrm{~h}$. To every well, $10 \mu 1$ of Cell Counting Kit- 8 reagent (Dojindo, Japan) was added and incubated at $37^{\circ} \mathrm{C}$ in a $5 \% \mathrm{CO}_{2}$ incubator for $3 \mathrm{~h}$. Then, optical density (O.D.) was measured by Multiskan EX ELISA reader (Thermo Electron, Finland) at $450 \mathrm{~nm}$ (with 620-nm reference).

Cell proliferation assays were performed at least 3 times for each cell line (in replicates of 12 wells for each concentration of leptin in each experiment). Data are presented as means \pm standard error for a representative experiment for each cell line.

Immunocytochemistry. Cover-slip preparations in 6-well plates were made in an aseptic condition. Cells were cultured in serum-free medium in 6-well plates for $18 \mathrm{~h}$. Above-mentioned concentrations of leptin were added and cells were incubated for 24 and $48 \mathrm{~h}$. Moreover, a separate experiment was conducted where cells were incubated with $50 \mathrm{ng} / \mathrm{ml}$ of leptin (along with control) for short durations, i.e., $30 \mathrm{~min}$, $1 \mathrm{~h}, 1.5 \mathrm{~h}$, and $2 \mathrm{~h}$. After that, cells were fixed with chilled acetone:methanol (1:1). Subsequently, cells were washed with PBS and endogenous peroxidase blocking was performed using $1 \%$ hydrogen peroxide for $10 \mathrm{~min}$. Cells were then treated with $0.2 \%$ Tween-20 with PBS for $20 \mathrm{~min}$ at room temperature and incubated with $3 \%$ non-fat milk in PBS for $1 \mathrm{~h}$ at room temperature to block the non-specific reacting sites, followed by incubation overnight at $4{ }^{\circ} \mathrm{C}$ with rabbit primary antibody against $\mathrm{Ob}-\mathrm{R}$ optimally diluted in PBS with 5\% milk. Afterwards, cells were rinsed in PBS and incubated for $30 \mathrm{~min}$ with biotinylated secondary antibody (anti-rabbit Igs, ABC Staining System, Santa Cruz, CA) at room temperature. Following the PBS wash, cells were incubated for 30 min with avidin-biotinylated horseradish peroxidase (HRP) complex at room temperature. After washing with PBS, the reaction was visualized by the peroxidase substrate diaminobenzidine (DAB). Subsequent to development of the proper color, the 
A

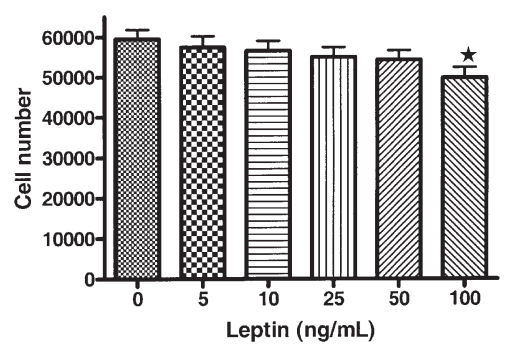

B

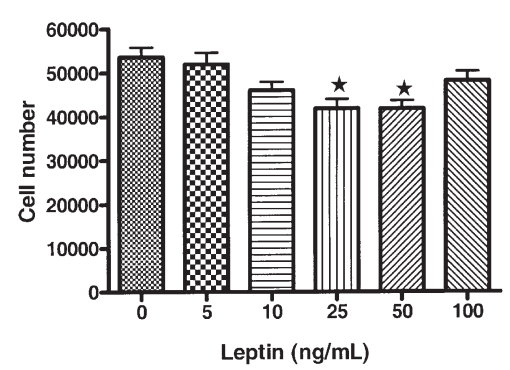

Figure 1. (A) MCF-7 cell proliferation assay after 24-h leptin treatment (ANOVA $\mathrm{p}=0.1171$, Dunnett's multiple comparison posttest $\mathrm{p}<0.01$ for 0 vs. $100 \mathrm{ng} / \mathrm{ml}$ ). (B) MCF-7 cell proliferation assay after 48-h leptin treatment (ANOVA $\mathrm{p}=0.0002$, Dunnett's multiple comparison posttest $\mathrm{p}<0.01$ for $0 \mathrm{vs}$. 25 and $50 \mathrm{ng} / \mathrm{ml})$.

cells were washed with deionized water and counterstained with hematoxylin. Finally, the cells were washed and dehydrated gradually through graded alcohol and mounted on glass-slides.

Western blot analysis. Cells were cultured in 6-well plates in serum-free medium, then treated with leptin and incubated for 24 and $48 \mathrm{~h}$ following the above-mentioned protocol. For extraction of total soluble proteins from the cultured cells, the Mammalian Cell - PE LB ${ }^{\mathrm{TM}}$ kit (Genotech, St. Louis, MO) containing EDTA, DTT and protease inhibitor was used. Cell lysates were sonicated and subsequently centrifuged at $13,000 \mathrm{rpm}$ for $10 \mathrm{~min}$ at $4^{\circ} \mathrm{C}$, and clear supernatants were collected. For the Western blot analysis, 10\% SDS-PAGE was used and proteins were transferred to PVDF membranes (Immobilon - P, Millipore, Billerica, MA). Primary antibodies against the following proteins were used for probing: $\mathrm{Ob}-\mathrm{Rb}$ (Linco, St. Louis, MO), Ob-R, leptin, Jak2, PI3K, Stat3, pStat3, PCNA (Abcam, Cambridge, MA), cyclin D1, Cox-2, VEGF, Bcl-2 (Alexis, AXXORA LLC, San Diego, CA), Bcl-x $\mathrm{L}_{\mathrm{L}}$, Bax, insulin, IGF-I, IGFBP3, IGF-IR $\alpha$, aromatase (Cell Signaling, Beverly, MA), CYP1A1 and CYP1B1 (except where indicated, all antibodies were from Santa Cruz, CA). Suitable secondary IgGs conjugated with alkaline phosphatase (AP) were used as secondary antibody. Proteins were detected by enhanced chemifluorescence (ECF substrate, Amersham, Newark, NJ) and developed in a Storm 840 system (Amersham, Piscataway, NJ).

\section{Results}

Cell proliferation assays. The following are representative results from multiple proliferation assays that were conducted for each cell line.
A

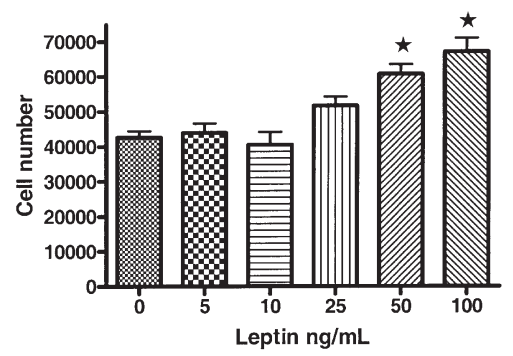

B

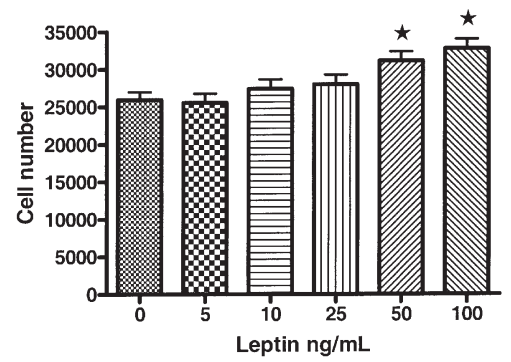

Figure 2. (A) MDA-MB-231 cell proliferation after 24-h leptin treatment (ANOVA $\mathrm{p}<0.0001$, Dunnett's multiple comparison posttest $\mathrm{p}<0.01$ for $0 \mathrm{vs.}$ 50 and $100 \mathrm{ng} / \mathrm{ml}$ ). (B) MDA-MB-231 cell proliferation after 48-h leptin treatment (ANOVA p $=0.0002$, Dunnett's multiple comparison posttest $\mathrm{p}<0.05$ for $0 \mathrm{vs} .50 \mathrm{ng} / \mathrm{ml}$, and $\mathrm{p}<0.01$ for $0 \mathrm{vs} .100 \mathrm{ng} / \mathrm{ml}$ ).

$M C F-7$. There was a dose-dependent decrease in cell numbers in this cell line following leptin treatment for $24 \mathrm{~h}$ in a serumfree system, with a statistically significant growth inhibitory effect observed at $100 \mathrm{ng} / \mathrm{ml}$ (Fig. 1A). A somewhat similar trend was observed after $48 \mathrm{~h}$ of leptin treatment, with 25 and $50-\mathrm{ng} / \mathrm{ml}$ doses exhibiting significantly inhibitory effects, but not the 100-ng/ml concentration (Fig. 1B). This appears contrary to some published reports on leptin's proliferative effects on this cell line (32).

$M D A-M B-231$. Fig. 2A and B illustrates the response of this cell line to leptin treatment for 24 and $48 \mathrm{~h}$. At the 24-h time point, leptin concentrations of 50 and $100 \mathrm{ng} / \mathrm{ml}$ elicited proliferative responses that were significantly higher than untreated cells. This same effect was maintained at the 48-h time point. There appeared to be a dose-dependent effect of leptin in promoting MDA-MB-231 cell growth. Frankenberry and colleagues recently reported proliferative effects of a lower dose $(40 \mathrm{ng} / \mathrm{ml})$ of leptin treatment in this cell line at the 48-h time point (33).

T47-D. Leptin exhibited mitogenic effects in this cell line, and displayed dose dependency (Fig. 3A and B). Leptin concentrations of 25,50 and $100 \mathrm{ng} / \mathrm{ml}$ were effective at promoting significantly greater cell growth compared to untreated cells at the 24-h time point, while only the 50- and $100-\mathrm{ng} / \mathrm{ml}$ concentrations maintained this effect at $48 \mathrm{~h}$. Laud and colleagues reported that 50- and 100-ng/ml leptin concentrations were effective in maintaining significantly higher cell numbers than untreated control as determined by thymidine incorporation experiments and cell proliferation assays following $24 \mathrm{~h}$ of leptin treatment (26). Our proliferation assay results on this cell line concur with these observations. 
A

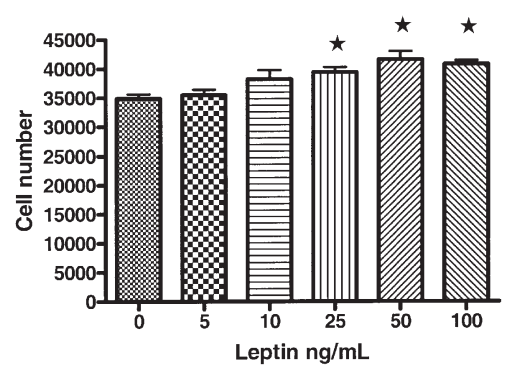

B

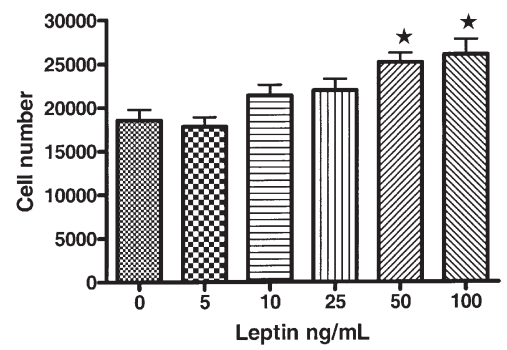

Figure 3. (A) T47-D cell proliferation after 24-h leptin treatment (ANOVA $\mathrm{p}<0.0001$, Dunnett's multiple comparison posttest $\mathrm{p}<0.05$ for $0 \mathrm{vs.} 25 \mathrm{ng} / \mathrm{ml}$, and $\mathrm{p}<0.01$ for 0 vs. 50 and $100 \mathrm{ng} / \mathrm{ml}$ ). (B) T47-D cell proliferation after 48-h leptin treatment (ANOVA $\mathrm{p}<0.0001$, Dunnett's multiple comparison posttest $\mathrm{p}<0.05$ for $0 \mathrm{vs.} .25 \mathrm{ng} / \mathrm{ml}$ and $\mathrm{p}<0.01$ for 0 vs. 50 and $100 \mathrm{ng} / \mathrm{ml}$ ).

A

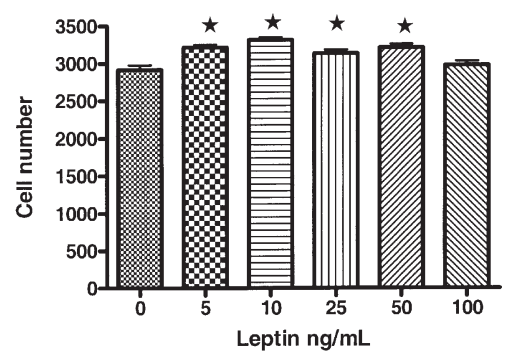

B

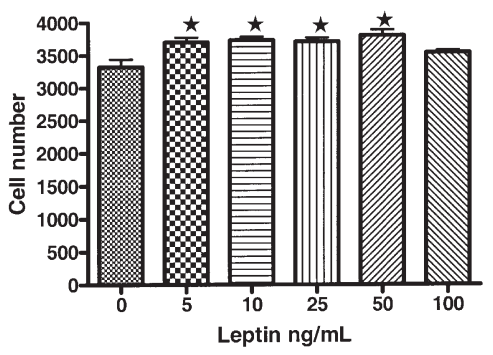

Figure 4. (A) SK-BR-3 cell proliferation after 24-h leptin treatment (ANOVA $\mathrm{p}<0.0001$, Dunnett's multiple comparison posttest $\mathrm{p}<0.01$ for 0 vs. $5,10,25$ and $50 \mathrm{ng} / \mathrm{ml}$ ). (B) SK-BR-3 cell proliferation after 48-h leptin treatment (ANOVA $\mathrm{p}<0.0001$, Dunnett's multiple comparison posttest $\mathrm{p}<0.01$ for $0 \mathrm{vs}$. $5,10,25$ and $50 \mathrm{ng} / \mathrm{ml})$.

$S K-B R-3$. Leptin treatment resulted in increased cell proliferation for this cell line at $5,10,25$, and $50 \mathrm{ng} / \mathrm{ml}$ but not at $100 \mathrm{ng} / \mathrm{ml}$ at both $24-$ and $48-\mathrm{h}$ time points. The effects of leptin at the mentioned doses were virtually identical at the two time points (Fig. 4A and B).

MDA-MB-361. Leptin also elicited increased cell proliferation for this cell line at $10,25,50$ and $100 \mathrm{ng} / \mathrm{ml}$ in a dose-
A

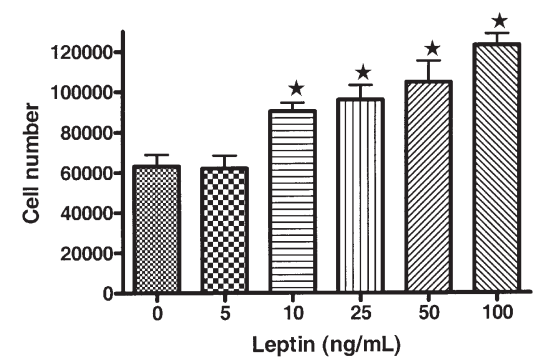

B

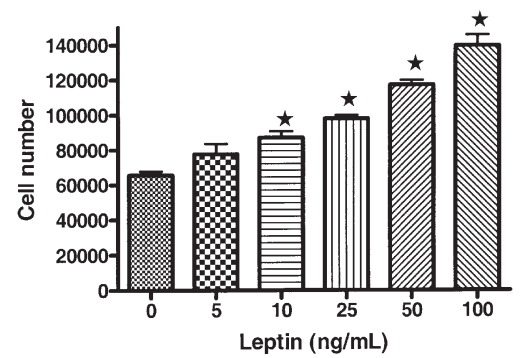

Figure 5. (A) MDA-MB-361 cell proliferation after 24-h leptin treatment (ANOVA $\mathrm{p}<0.0001$, Dunnett's multiple comparison posttest $\mathrm{p}<0.05$ for 0 vs. $10 \mathrm{ng} / \mathrm{ml}$ and $\mathrm{p}<0.01$ for 0 vs. 25,50 and $100 \mathrm{ng} / \mathrm{ml}$ ). (B) MDA-MB-361 cell proliferation after 48-h leptin treatment (ANOVA $\mathrm{p}<0.0001$, Dunnett's multiple comparison posttest $\mathrm{p}<0.01$ for $0 \mathrm{vs}$. $10,25,50$ and $100 \mathrm{ng} / \mathrm{ml}$ ).

dependent manner at both 24- and 48-h time points (Fig. 5A and B).

Immunocytochemical analysis. The immunocytochemical analyses showed the presence of Ob-R in all 5 examined cell lines. In general, the immunoreactivity for $\mathrm{Ob}-\mathrm{R}$ was confined to the cell membrane and cytoplasm as observed in human breast tumors by Ishikawa et al (23). However, the distribution patterns of Ob-R were different among these cell lines. In MCF-7 and MDA-MB-231 cells treated with leptin for 24 and $48 \mathrm{~h}$, four main types of $\mathrm{Ob}-\mathrm{R}$ distribution were observed, namely, peripheral, crescent, bipolar and unipolar (Fig. 6A-D for MCF-7; Fig. 6E-H for MDA-MB-231). In the majority of MCF-7 cells treated for longer durations (i.e., 24 and $48 \mathrm{~h}$ ), Ob-R was expressed around the periphery. On the contrary, in MCF-7 cells treated with leptin for short durations (i.e., $30 \mathrm{~min}$ to $2 \mathrm{~h}$ ), the intensity of Ob-R immunostaining was usually weaker and no specific pattern of distribution was observed (Fig. 7A and B). The above-mentioned four distribution patterns were also observed in MDA-MB-231 cells treated for both short and long durations. However in the shorter time-course treatments Ob-R immunoexpression was primarily the crescent pattern in the majority of MDAMB-231 cells; whereas a unipolar distribution was observed with longer leptin treatment times for this cell line. It also appeared that in MDA-MB-231 cells, the crescent pattern decreased while the unipolar pattern increased in relation with length of exposure to leptin. The expression of $\mathrm{Ob}-\mathrm{R}$ in T47-D and SK-BR-3 cells did not show any specific staining pattern in response to either short- or long-term leptin exposure (Fig. 8A-E for T47-D; Fig. 9A-C for SK-BR-3). Similarly, no pattern of Ob-R expression was observed in MDA-MB361 cells in the shorter time-course experiments (Fig. 9D). In contrast, many cells exhibited a unipolar distribution of 


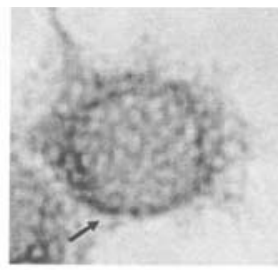

A

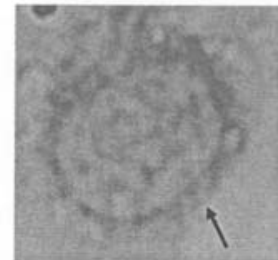

E

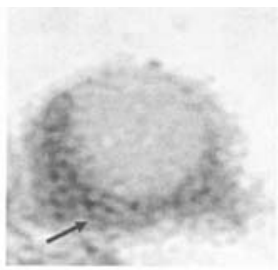

B

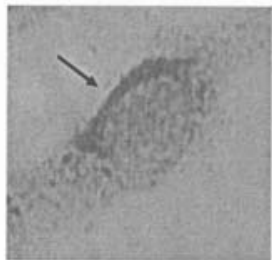

$\mathbf{F}$

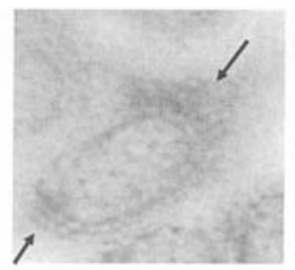

C

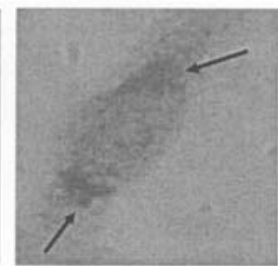

G

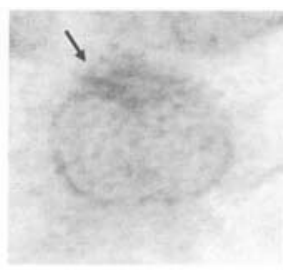

D

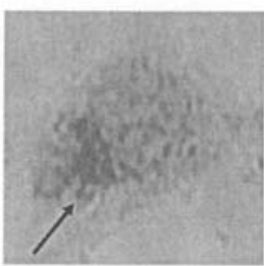

H

Figure 6. Expression of Ob-R in MCF-7 cells (A-D) and MDA-MB-231 cells (E-H). The cells were treated with $50 \mathrm{ng} / \mathrm{ml}$ of leptin for $24 \mathrm{~h}$.

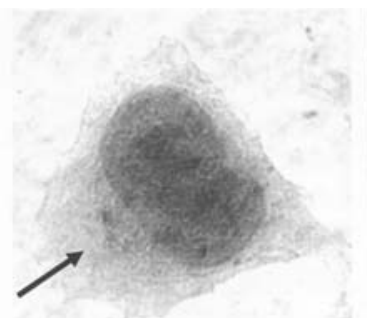

A

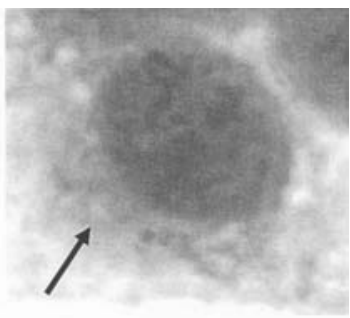

B
Figure 7. Expression of Ob-R in MCF-7 cells, which were incubated with $50 \mathrm{ng} / \mathrm{ml}$ of leptin for $30 \mathrm{~min}(\mathrm{~A})$ and $2 \mathrm{~h}(\mathrm{~B})$.

immunoreactivity for $\mathrm{Ob}-\mathrm{R}$ in the longer term leptin treatments (Fig. 9E and F).

Western blot analysis. A summary of results for the Western blot analyses are presented in Table I. Details for individual cell lines are presented below.

MCF-7. MCF-7 cells treated with leptin for $24 \mathrm{~h}$ had increased expression of $\mathrm{Ob}-\mathrm{Rb}$, Jak2, PI3K, Stat 3 and p-Stat 3 in a dosedependent manner up to $50 \mathrm{ng} / \mathrm{ml}$. Interestingly, MCF-7 cells treated with $100 \mathrm{ng} / \mathrm{ml}$ of leptin for $24 \mathrm{~h}$ exhibited a decline of expression of all the above-mentioned proteins. In contrast, MCF-7 cells treated for $48 \mathrm{~h}$ exhibited no consistent results for these proteins. Inconsistent levels were observed in Ob-R and leptin expression. Also, PCNA showed inconsistent expression in response to leptin; whereas no change was noted in VEGF expression. However, cyclin D1 expression increased after $48 \mathrm{~h}$ of leptin exposure ranging in concentration from 25 to $100 \mathrm{ng} / \mathrm{ml}$. Similarly, increases of Cox-2 levels were observed in $48 \mathrm{~h}$ in relation to leptin concentrations with a maximum response at $50 \mathrm{ng} / \mathrm{ml}$. There was increased expression of Bax in MCF-7 cells treated with 10 and $25 \mathrm{ng} /$ $\mathrm{ml}$ of leptin for both 24 and $48 \mathrm{~h}$; but no definite increasing trends were recorded in the case of Bcl-2 and $\mathrm{Bcl}-\mathrm{x}_{\mathrm{L}}$. On the other hand, IGF-IR $\alpha$ increased in a dose-dependent manner

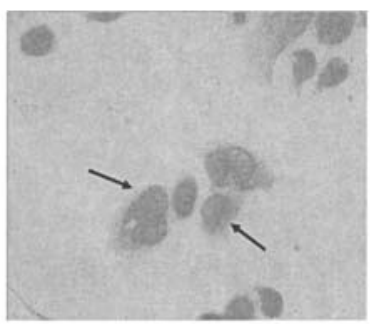

A

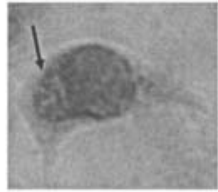

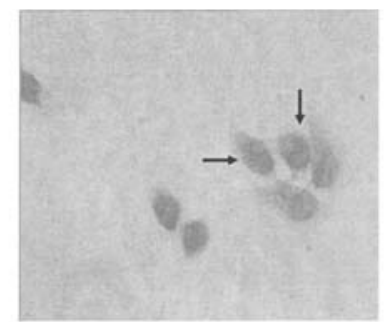

B

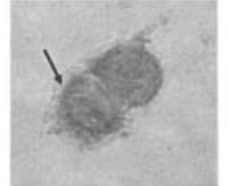

D

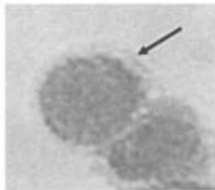

E
Figure 8. Expression of Ob-R in T47-D cells, treated with $50 \mathrm{ng} / \mathrm{ml}$ of leptin for $24 \mathrm{~h}(\mathrm{~A}-\mathrm{E})$.

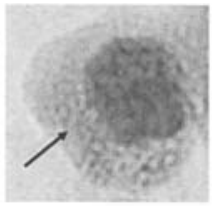

A

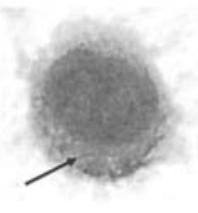

D

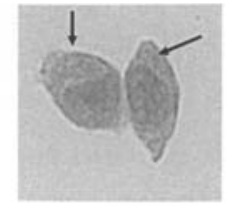

B

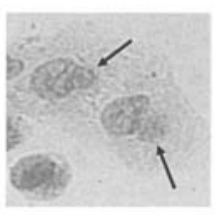

E

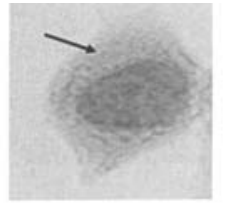

c

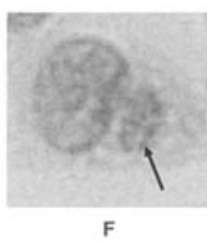

Figure 9. Expression of Ob-R in SK-BR-3 and MDA-MB-361 cells. (A-C) SK-BR-3 cells treated with $100 \mathrm{ng} / \mathrm{ml}$ of leptin for $48 \mathrm{~h}$. (D) MDA-MB-361 cell treated with $50 \mathrm{ng} / \mathrm{ml}$ of leptin for $1 \mathrm{~h}$. (E and F) MDA-MB-361 cells treated with $100 \mathrm{ng} / \mathrm{ml}$ of leptin for $48 \mathrm{~h}$. 
Table I. Summary of the findings for Western blot analyses for proteins related to leptin.

\begin{tabular}{|c|c|c|c|c|c|}
\hline & MCF-7 & MDA-MB-231 & T47-D & SK-BR-3 & MDA-MB-361 \\
\hline $\mathrm{Ob}-\mathrm{Rb}$ & Response $\uparrow$ & Response $\uparrow$ & Inconsistent & Inconsistent & Response $\uparrow \Uparrow$ \\
\hline $\mathrm{Ob}-\mathrm{R}$ & Inconsistent & Inconsistent & Inconsistent & Response $\uparrow \Uparrow$ & Inconsistent \\
\hline Jak2 & Response $\uparrow$ & Inconsistent & Response $\uparrow \Uparrow$ & Response $\uparrow$ & Inconsistent \\
\hline PI3K & Response $\uparrow$ & Inconsistent & Inconsistent & Response $\uparrow$ & Response $\Uparrow$ \\
\hline Stat3 & Response $\uparrow$ & Inconsistent & Response $\uparrow \Uparrow$ & Inconsistent & Response $\Uparrow$ \\
\hline p-Stat3 & Response $\uparrow$ & Response $\Uparrow$ & Response $\Uparrow$ & No change & No change \\
\hline Leptin & Inconsistent & Inconsistent & Inconsistent & Response $\uparrow \Downarrow$ & Inconsistent \\
\hline Bcl-2 & No change & Inconsistent & Inconsistent & Not detected & Response $\downarrow \Uparrow$ \\
\hline Bcl- $x_{L}$ & Inconsistent & Response $\Uparrow$ & Response $\Downarrow$ & Inconsistent & Inconsistent \\
\hline Bax & Response $\uparrow \Uparrow$ & Inconsistent & Inconsistent & Response $\Uparrow$ & Inconsistent \\
\hline PCNA & Inconsistent & Response $\uparrow \Uparrow$ & Response $\Uparrow$ & Response $\downarrow \Uparrow$ & Response $\Uparrow$ \\
\hline Cyclin D1 & Response $\Uparrow$ & Response $\uparrow \Uparrow$ & Response $\uparrow \Uparrow$ & Response $\Uparrow$ & Inconsistent \\
\hline Cox-2 & Response $\Uparrow$ & Inconsistent & Inconsistent & Response $\uparrow$ & Response $\uparrow \Uparrow$ \\
\hline VEGF & No change & Inconsistent & Inconsistent & Response $\Uparrow$ & Response $\uparrow \Uparrow$ \\
\hline Insulin & Not detected & Not detected & Not detected & Not detected & Response $\Uparrow$ \\
\hline IGF-I & Inconsistent & Not detected & Not detected & Response $\uparrow \Uparrow$ & Inconsistent \\
\hline IGFBP3 & Inconsistent & Inconsistent & Not detected & Response $\uparrow \Uparrow$ & Inconsistent \\
\hline IGF-IR $\alpha$ & Response $\uparrow$ & Inconsistent & No change & Response $\downarrow \Uparrow$ & Response $\downarrow \Uparrow$ \\
\hline CYP19 & Inconsistent & Inconsistent & Inconsistent & No change & Inconsistent \\
\hline CYP1A1 & Inconsistent & Inconsistent & Inconsistent & Inconsistent & Inconsistent \\
\hline CYP1B1 & Response $\uparrow \Uparrow$ & Inconsistent & Inconsistent & Inconsistent & Response $\uparrow$ \\
\hline
\end{tabular}

$(\uparrow)$ An increase with 24-h incubation with increasing concentrations of leptin. ( $\downarrow$ ) A decrease with 24-h leptin incubation. ( $\uparrow)$ An increase after $48 \mathrm{~h}$ and $(\Downarrow)$ a decrease after 48 -h incubation with leptin.

after $24 \mathrm{~h}$; however, IGF-I and IGFBP3 expression was inconsistent, and we were unable to detect the expression of insulin. Further, an increase in CYP1B1 expression was observed at both 24 and $48 \mathrm{~h}$ with all concentrations of leptin, but aromatase and CYP1A1 levels were inconsistently affected by time and the addition of leptin.

$M D A-M B-231$. After 24-h exposure to leptin, there was a trend for $\mathrm{Ob}-\mathrm{Rb}$ expression to increase with up to $25 \mathrm{ng} / \mathrm{ml}$ of leptin and then decline at higher leptin concentrations in MDA-MB-231 cells. On the other hand, no consistent changes were detected for Ob-R, leptin, Jak2, PI3K and Stat3 expression at both 24 and $48 \mathrm{~h}$. Nevertheless, p-Stat 3 exhibited an increased level after both 24- and 48-h incubation with leptin. It is interesting to note that PCNA and cyclin D1 expression was increased in cells treated with leptin for both 24 and $48 \mathrm{~h}$; although Cox-2 and VEGF expression was inconsistent. Moreover, inconsistent expression levels were observed for Bcl-2 and Bax; whereas Bcl- $\mathrm{x}_{\mathrm{L}}$ showed increased expression at the 48-h time point. We did not detect insulin and IGF-I protein expression in MDA-MB-231 cells. On the other hand, IGFBP3, IGF-IR $\alpha$, and enzymes of estrogenic pathways such as aromatase, CYP1A1 and CYP1B1 revealed inconsistent levels in relation with different concentrations of leptin and time of incubation.

T47-D. There were no consistent patterns of expression in relation to leptin treatment in T47-D cells for $\mathrm{Ob}-\mathrm{Rb}$ and $\mathrm{Ob}-\mathrm{R}$.
In contrast, Jak2 and Stat 3 expression increased with higher concentrations of leptin after both 24- and 48-h exposure to leptin. However, p-Stat 3 showed increased expression only in 48 -h leptin-treated cells from 25 - to $100-\mathrm{ng} / \mathrm{ml}$ concentrations. Inconsistent results were found in the case of PI3K and leptin expression. Although there was no effect of exogenous leptin on PCNA after $24 \mathrm{~h}$, increasing levels of PCNA were noted in cells incubated with $10-100 \mathrm{ng} / \mathrm{ml}$ of leptin for $48 \mathrm{~h}$. Also, cyclin D1 levels showed higher expression at both 24 and $48 \mathrm{~h}$ with increasing leptin concentrations compared to controls. On the other hand, Cox-2, VEGF, Bcl-2 and Bax expression was inconsistently affected by time and leptin concentration. T47-D cells had lower expression of $\mathrm{Bcl}-\mathrm{x}_{\mathrm{L}}$ with increasing concentrations of leptin in comparison with controls following 24-h incubation and also Bcl- $\mathrm{x}_{\mathrm{L}}$ expression was lower with increasing concentrations of leptin after $48 \mathrm{~h}$ of exposure. Expression of insulin, IGF-I and IGFBP-3 was not detected in T47-D cells. IGF-IR $\alpha$ expression was detected but no marked alterations were observed with leptin administration. Aromatase, CYP1A1 and CYP1B1 did not exhibit any consistent level of expression in relation with various leptin concentrations.

$M D A-M B-361$. In MDA-MB-361 cells, Ob-Rb expression increased at both 24 and $48 \mathrm{~h}$, up to $50 \mathrm{ng} / \mathrm{ml}$ leptin. PI3K and Stat 3 increased after $48 \mathrm{~h}$ in MDA-MB-361 cells incubated with leptin in a dose-dependent manner; however, no change was observed in p-Stat3 levels. Inconsistent levels of Ob-R, 
Jak2 and leptin expression were recorded in leptin-administered MDA-MB-361 cells compared to controls. Similarly, Bcl- $\mathrm{x}_{\mathrm{L}}$ and Bax revealed inconsistent levels of expression. For Bcl-2, there was a gradual decrease in expression as leptin increased at $24 \mathrm{~h}$ but there was a dose-dependent increase after $48 \mathrm{~h}$. PCNA levels were also higher after $48 \mathrm{~h}$ at all leptin concentrations. Cox-2 exhibited higher expression levels at 5 and $10 \mathrm{ng} / \mathrm{ml}$ leptin in both 24- and 48-h cells; however, the levels declined afterwards. Further, VEGF expression increased at both the 24- and 48-h time periods, particularly at $100 \mathrm{ng} /$ ml leptin, while cyclin D1, IGF-I and IGFBP3 exhibited inconsistent levels of expression in response to the addition of leptin regardless of the concentration used. In contrast to the three cell lines described above, insulin was expressed in MDA-MB-361 cells, and furthermore, an increase of insulin production was observed in 25, 50 and $100 \mathrm{ng} / \mathrm{ml}$ leptin-treated cells after 48-h incubation; but the levels were inconsistent in cells exposed to leptin for only $24 \mathrm{~h}$. IGF-IR $\alpha$ levels declined at $24 \mathrm{~h}$ with increasing leptin concentrations; whereas there was an increase of IGF-IR $\alpha$ expression in a dose-dependent manner at $48 \mathrm{~h}$. Higher expression of CYP1B1 with leptin treatment compared to no leptin was noted in MDA-MB-361 cells after $24 \mathrm{~h}$; whereas a decline was found at $48 \mathrm{~h}$. On the other hand, both aromatase and CYP1A1 levels were inconsistent.

$S K-B R-3$. In SK-BR-3 cells, there was a slight increase in Ob-R levels after $24 \mathrm{~h}$ with intermediate levels of leptin but a decrease at the $100 \mathrm{ng} / \mathrm{ml}$ level. After $48 \mathrm{~h}$ there was a dosedependent increase of this protein. The expression levels of $\mathrm{Ob}-\mathrm{Rb}$ were inconsistent, while there was a gradual increase of leptin expression at $24 \mathrm{~h}$, but a gradual decrease at $48 \mathrm{~h}$ with increasing leptin concentration. Among the signaling proteins, Jak2 exhibited increased levels at 25, 50 and $100 \mathrm{ng} /$ $\mathrm{ml}$ leptin after $24 \mathrm{~h}$ and higher expression of PI3K was observed in leptin-treated cells at the 24-h time point but at $48 \mathrm{~h}$ these proteins were not affected by leptin. No significant alterations or trends were recorded for either Stat 3 or p-Stat 3 expression. At $24 \mathrm{~h}$, Bax levels increased initially at $5 \mathrm{ng} / \mathrm{ml}$ of leptin, but decreased afterwards. After $48 \mathrm{~h}$, Bax expression increased to its highest level at $50 \mathrm{ng} / \mathrm{ml}$ leptin treatment. Interestingly, there was no detectable $\mathrm{Bcl}-2$ expression in SK-BR-3 cells; while Bcl- $x_{\mathrm{L}}$ levels were inconsistent in response to the addition of leptin at both 24 and $48 \mathrm{~h}$. In contrast, PCNA, cyclin D1 and VEGF increased in a dosedependent manner at the 48-h time point. However, there was a decreasing trend for expression of PCNA in 24-h treated cells. On the other hand, increased Cox-2 expression was observed at $24 \mathrm{~h}$. After $24 \mathrm{~h}$, IGF-I expression increased in leptin-treated cells, and there was a gradual increase in a dosedependent manner up to $50 \mathrm{ng} / \mathrm{ml}$ at $48 \mathrm{~h}$. Moreover, there was an increase in IGFBP3 levels in a dose-dependent manner up to $50 \mathrm{ng} / \mathrm{ml}$ at both 24 and $48 \mathrm{~h}$. On the other hand, IGF-IR $\alpha$ levels showed a decline at $24 \mathrm{~h}$ with increasing leptin concentrations, but at $48 \mathrm{~h}$ expression of IGF-IR $\alpha$ increased in a dose-dependent manner. As with three of the four other cell lines there was no detectable expression of insulin in the SK-BR-3 cell line. Furthermore, no changes in aromatase expression were observed in SK-BR-3 cells with varying concentrations of leptin. Additionally, CYP1A1 and
CYP1B1 expression was not consistently affected by the addition of leptin at either time point.

\section{Discussion}

The incidences of both obesity and breast cancer in the United States are continuing to increase $(34,35)$. Furthermore, the incidence of breast cancer is also increasing globally, and this trend is partly due to dietary and lifestyle changes including obesity and less physical activity (36). Obesity is a known risk factor for postmenopausal breast cancer (1). Furthermore, obesity may affect prognosis through numerous pathways including hormonal profiles, co-morbidities that can interfere with treatment, and other as yet unknown mechanisms (37). The relationship between obesity and breast cancer pathology is a complex phenomenon, and several factors, apart from estrogen, such as insulin, IGF-I and leptin may be involved in this complicated disease process $(38,39)$.

A growing body of in vitro evidence indicates that proliferation of breast cancer cells is influenced by addition of leptin. Recently, Yin et al (40) observed that leptin stimulated the growth of MCF-7 and T47-D human breast cancer cells in a time- and dose-dependent fashion. Similar findings were previously recorded by Dieudonne et al (32) and Okumura et al (41) in MCF-7 cells as well as in T-47D cells by Hu et al (25) and Laud et al (26) and in ZR-75-1 cells by Somasundar et al (42) and Chen et al (28). In the present study we also noted an overall growth stimulation effect of leptin in the examined cell lines, i.e., T47-D, MDA-MB-361, MDA-MB231 and SK-BR-3. However we were unable to find a positive effect in MCF-7 cells by leptin using a cell proliferation assay.

Similar to the observation of Dieudonne et al (32) in MCF-7 cells, the current study identified Ob-R expression by immunocytochemistry in the above-mentioned five cell lines. There appeared to be different patterns of cellular location for the protein, however, the significance (if any) with respect to leptin's action in mammary tumorigenesis is not clear at the present time. It appears that there are some trends of Ob-R localization within the individual breast cancer cell lines, particularly in MCF-7, MDA-MB-231 and MDA-MB-361 cell lines. Most probably, this phenomenon is associated with the progression of the cell cycle; and perhaps cytoskeleton elements are also involved in this process. Nevertheless, it has been documented in this study that $\mathrm{Ob}-\mathrm{R}$ is not a static entity.

It appears that leptin induces multiple signaling pathways in breast cancer cells. Hu et al (25) observed increased levels of p-Stat 3 in leptin-stimulated human breast epithelial cells (HBL100) and breast cancer cells (T47-D) compared to the corresponding untreated controls. The results of the present study pertaining to T47-D cells support these previous findings. Activation of signaling proteins following leptin exposure was clearly indicated in MCF-7 cells, another estrogen-dependent cell line. Several studies reported that stimulation of MCF-7 cells with leptin induced multiple signaling proteins including Stat3 $(32,40,43)$. These earlier studies also showed an increase in p-Stat3 levels by leptin, as we do in the present study. Interestingly, our study indicated an enhanced expression of Jak-2 and PI3K in SK-BR-3 cells (estrogen-independent cells), similar to MCF-7 cells. However, activation of Stat-3 was not observed in SK-BR-3 cells. 
Dieudonne et al (32) postulated that leptin, through Stat3 activation, may stimulate aromatase (CYP19) gene expression in MCF-7 cells. A strong association between CYP19 gene expression and the expression of the Cox-2 gene has been reported in breast cancer (44). Additionally, Catalano et al (21) reported a significant increase of aromatase enzymatic activity and protein content in MCF-7 cells upon leptin treatment. However, the present study did not demonstrate such effects of leptin in any of the examined cell lines. Regarding other estrogen metabolizing cytochrome P450 enzymes, we noticed an increased level of expression of CYP1B1 in estrogendependent MCF-7 and MDA-MB-361 cells, in response to leptin treatment. This observation may be of interest because CYP1B1 is known to be involved in the oxidative metabolism of estrogen (4-hydroxylation) (45) and activation of exogenous carcinogens as a phase I enzyme (46). Accumulating evidence suggests an association of CYP1B1 with risk and prognosis in breast cancer $(47,48)$.

Tumorigenesis involves numerous pathological processes such as angiogenesis, proliferation and cell-cycle progression as well as evading apoptosis. All these phenomena are closely interrelated. Overall, the evidence suggests that the progressive inhibition of apoptosis and induction of angiogenesis may contribute to tumor initiation, growth and metastasis in the pathogenesis of breast cancer (49). VEGF, a key regulator of angiogenesis, was shown to induce the expression of the antiapoptotic protein, Bcl-2, in human breast cancer cells (50). On the other hand, Cox-2 (the inducible form that converts arachidonic acid into prostaglandins and thromboxanes) expression is associated with tumor cell proliferation, resistance to apoptosis and induction of angiogenesis (51). In the study by Okumura et al (41), there were no significant effects of leptin on the expression of apoptotic markers including Bax, $\mathrm{Bcl}-2$ and $\mathrm{Bcl}-\mathrm{x}_{\mathrm{L}}$ in MCF-7 cells indicating that leptin induced MCF-7 cell proliferation without altering apoptosis. However, their study recorded up-regulation of cell cycle-regulated proteins such as cyclin D1 in MCF-7 cells with leptin (41). Similarly, Chen et al (28) observed that leptin stimulated expression of cyclin D1 in cell cycle progression of ZR-75-1 breast cancer cells. In the present study we found no definitive trend for the expression of apoptotic markers in response to leptin as there were variations in expression of these markers among the different cell lines. However, in the majority of cell lines, an up-regulation of proliferation and cell-cycle progression markers such as PCNA and cyclin D1 was found following leptin exposure. Overall this suggests that leptin's primary effect concerning increasing breast cancer cell numbers is directly on proliferation.

An association between leptin and Cox-2 activity has been reported. For example, it has been demonstrated that increased leptin production in the presence of arachidonic acid was reduced by selective Cox- 2 inhibitors, which also reversed the proliferation of estrogen-responsive and estrogen receptorpositive human breast cancer cells with leptin administration (52). Recently, a study on esophageal adenocarcinoma cells has shown that leptin stimulated cell proliferation and inhibited apoptosis through activation of Cox-2 and prostaglandin E2 production (53). In the current study, Cox-2 levels increased in MCF-7 cells following longer duration of incubation with leptin. Additionally, two HER2/neu-positive cell lines, i.e.,
SK-BR-3 and MDA-MB-361 cells, exhibited higher levels of Cox-2 and VEGF expression after leptin treatment. The angiogenic role of leptin has been documented in previous studies $(54,55)$. It is worthy to mention that obesity, HER $2 /$ neu overexpression and tumor angiogenesis are all considered as poor prognostic factors in breast cancer (37,56-58); and an association between HER2/neu overexpression and angiogenesis has been recorded (59). Therefore, HER2/neu-positive cells in the tumor microenvironment may influence the disease course immensely under obese conditions.

Expression of the angiogenic stimulator VEGF is influenced by insulin, growth factors such as PDGF, EGF, TNF- $\alpha$ and TGF- $\beta$, and several cytokines, as reviewed by Liekens et al (60) and Hausman and Richardson (61). On the other hand, tumor microvascular endothelial cells supply different growth factors including IGF-I (62). It has been hypothesized that leptin has an association with insulin and IGF-I (24). There are also supportive data from human subjects (63). However, the present study did not indicate a clear association between leptin and the insulin/IGF-I system at the intracellular level. It has been reported that higher circulating levels of IGF-I predict risk for premenopausal but not postmenopausal breast cancer (64). The mitogenic and survival effects of IGF-I on both normal and malignant breast cells are mediated primarily through the IGF-IR, which is overexpressed and highly activated in breast tumors (65). Some recent studies on primary breast tumor tissues reported approximately $50 \%$ positive immunostaining for IGF-IR $(66,67)$. Nevertheless, expression of IGF-I and IGF-IR genes may undergo substantial change over the course of breast tumorigenesis (68). Moreover, Garofalo et al (24) proposed that factors such as insulin and IGF-I are possibly associated with the overexpression of leptin and its receptor in breast cancer.

Interestingly, Eisenberg et al (69) demonstrated that leptin might provoke the phosphorylation of HER $2 /$ neu/c-erbB-2 and thus enhance its oncogenic potential independently of HER family ligands or its overexpression. Furthermore, Menendez et al (70) observed that inhibition of fatty acid synthase suppressed HER2/neu expression in human breast cancer SKBR-3 cells. However, in a recent study using MMTV-neu mice with diet-induced obesity and elevated serum leptin levels there was little impact on mammary tumor development compared to lean mice (71). However, it should be noted that the serum leptin levels were in the low range compared to in vitro studies and serum levels frequently documented in obese humans. In the present study we observed an influence of leptin on the SK-BR-3 cell line, which is estrogen receptor-negative and HER2/neu-positive, with reference to leptin production, related signaling proteins (Jak2 and PI3K), tumor growth markers (PCNA, cyclin D1, Cox-2 and VEGF) and IGF-I.

With respect to serum leptin levels a number of studies have addressed this issue. Several studies failed to demonstrate a relationship between circulating leptin levels and breast cancer risk (72-77). However, the majority of these studies were conducted on a small number of cases. Interestingly, an inverse association of blood leptin levels with breast cancer was recorded in two studies on premenopausal women $(78,79)$. Also, in an earlier study, Mantzoros et al (80) did not find any significant correlation between serum leptin concentrations and premenopausal carcinoma in situ of the breast. Since obesity is 
not a risk factor for premenopausal breast cancer, this finding is not unexpected. On the other hand, some studies observed higher blood levels of leptin among patients with breast cancer (81-84). Additionally, Goodwin et al (85) noticed that plasma leptin levels were strongly correlated with insulin and significantly higher with advanced tumor stage, higher tumor grade and estrogen receptor negativity; but no relation with lymph node metastasis was found. Recently, Miyoshi et al (86) demonstrated a significant association of high intratumoral leptin receptor mRNA levels with a poor prognosis which was observed only in the subset of the patients with high intratumoral leptin mRNA levels or high serum leptin levels. It is of interest to mention that inhibition of mammary tumor development has been demonstrated in leptin-deficient mice (22).

A large number of epidemiological studies indicate obesity as an important risk factor for postmenopausal breast cancer and a poor prognostic factor for all breast cancer cases. Further, a growing body of evidence shows that leptin may play a significant role in this complex pathological process. However, there is a need for detailed investigations on the estrogendependent and -independent status of breast cancer with reference to how leptin mediates its effects. Interestingly, the present study revealed that the impact of leptin is influenced by additional cell characteristics, not just estrogen receptor status. Because breast cancer cell lines represent tumor cells the present results may actually be a better reflection of breast cancer prognosis. It is known that treatment modalities are limited in patients with estrogen-independent tumors. Therefore, a proper understanding of the relationship between leptin and the estrogen-independent state may provide lifesaving strategies for treatment. Overall, the results of this study suggest that leptin may contribute significantly to the pathology of breast cancer. However, the influence of leptin should be viewed in relation with other factors.

\section{Acknowledgements}

This study was funded by The Hormel Foundation and the Breast Cancer Research Foundation. We thank Dr Jeffrey Salisbury of the Mayo Foundation for helpful insights into the immunocytochemistry work.

\section{References}

1. Cleary MP and Maihle NJ: The role of body mass index in the relative risk of developing premenopausal versus postmenopausal breast cancer. Proc Soc Exp Biol Med 216: 28-43, 1997.

2. Sweeney C, Blair CK, Anderson KE, Lazovich D and Folsom AR: Risk factors for breast cancer in elderly women. Am J Epidemiol 160: 868-875, 2004.

3. Loi S, Milne RL, Friedlander ML, McCredie MR, Giles GG, Hopper JL and Phillips KA: Obesity and outcomes in premenopausal and postmenopausal breast cancer. Cancer Epidemiol Biomarkers Prev 14: 1686-1691, 2005.

4. Porter GA, Inglis KM, Wood LA and Veugelers PJ: Effect of obesity on presentation of breast cancer. Ann Surg Oncol 13: 327-332, 2006

5. Cleary MP, Grande JP and Maihle NJ: Effect of high fat diet on body weight and mammary tumor latency in MMTV-TGF-alpha mice. Int J Obes Relat Metab Disord 28: 956-962, 2004.

6. Hakkak R, Holley AW, MacLeod SL, Simpson PM, Fuchs GJ, Jo CH, Kieber-Emmons $\mathrm{T}$ and Korourian S: Obesity promotes 7,12-dimethylbenz(a)anthracene-induced mammary tumor development in female zucker rats. Breast Cancer Res 7: R627-R633, 2005.
7. McTiernan A: Obesity and cancer: the risks, science, and potential management strategies. Oncology 19: 871-881, 2005.

8. Lorincz AM and Sukumar S: Molecular links between obesity and breast cancer. Endocr Relat Cancer 13: 279-292, 2006

9. Russo J and Russo IH: Genotoxicity of steroidal estrogens. Trends Endocrinol Metab 15: 211-214, 2004.

10. Perks CM and Holly JM: The insulin-like growth factor (IGF) family and breast cancer. Breast Dis 18: 45-60, 2003.

11. Godsland IF: Oestrogens and insulin secretion. Diabetologia 48: 2213-2220, 2005

12. Kaaks R: Nutrition, insulin, IGF-I metabolism and cancer risk: a summary of epidemiological evidence. Novartis Found Symp 262: 247-260, 2004.

13. Popruk S, Tungtrongchitr R, Pongpaew P, Phonrat B, Tungtrongchitr A, Tribunyatkul S, Paksanont S, Vudhivai N and Schelp FP: Relationship between soluble leptin receptor, leptin, lipid profiles and anthropometric parameters in overweight and obese Thai subjects. J Med Assoc Thai 88: 220-227, 2005.

14. Bednarek-Tupikowska G, Filus A, Kuliczkowska-Plaksej J, Tupikowski K, Bohdanowicz-Pawlak A and Milewicz A: Serum leptin concentrations in pre- and postmenopausal women on sex hormone therapy. Gynecol Endocrinol 22: 207-212, 2006.

15. Garofalo C and Surmacz E: Leptin and cancer. J Cell Physiol 207: 12-22, 2006.

16. Houseknecht KL and Spurlock ME: Leptin regulation of lipid homeostasis: dietary and metabolic implications. Nutr Res Rev 16: 83-96, 2003

17. Myers MG Jr: Leptin receptor signaling and the regulation of mammalian physiology. Recent Prog Horm Res 59: 287-304, 2004.

18. Hegyi K, Fulo K, Kovacs K, Toth S and Falus A: Leptin-induced signal transduction pathways. Cell Biol Int 28: 159-169, 2004.

19. Fruhbeck G: Intracellular signaling pathways activated by leptin. Biochem J 393: 7-20, 2006

20. Ahima RS and Osei SY: Leptin signaling. Physiol Behav 81: 223-241, 2004.

21. Catalano S, Marsico S, Giordano C, Mauro L, Rizza P, Panno ML and Ando S: Leptin enhances, via AP-1, expression of aromatase in the MCF-7 cell line. J Biol Chem 278: 28668-28676, 2003.

22. Cleary MP, Phillips FC, Getzin SC, Jacobson TL, Jacobson MK, Christensen TA, Juneja SC, Grande JP and Maihle NJ: Genetically obese MMTV-TGF-alpha/Lep(ob)Lep(ob) female mice do not develop mammary tumors. Breast Cancer Res Treat 77: 205-215, 2003.

23. Ishikawa $\mathbf{M}$, Kitayama $\mathbf{J}$ and Nagawa $\mathrm{H}$ : Enhanced expression of leptin and leptin receptor (OB-R) in human breast cancer. Clin Cancer Res 10: 4325-4331, 2004.

24. Garofalo C, Koda M, Cascio S, Sulkowska M, Kanczuga-Koda L, Golaszewska J, Russo A, Sulkowski S and Surmacz E: Increased expression of leptin and the leptin receptor as a marker of breast cancer progression: possible role of obesity-related stimuli. Clin Cancer Res 12: 1447-1453, 2006.

25. Hu X, Juneja SC, Maihle NJ and Cleary MP: Leptin - a growth factor in normal and malignant breast cells and for normal mammary gland development. J Natl Cancer Inst 94: 1704-1711, 2002.

26. Laud K, Gourdou I, Pessemesse L, Peyrat JP and Djiane J: Identification of leptin receptors in human breast cancer: functional activity in the T47-D breast cancer cell line. Mol Cell Endocrinol 188: 219-226, 2002.

27. Sulkowska M, Golaszewska J, Wincewicz A, Koda M, Baltaziak M and Sulkowski S: Leptin - from regulation of fat metabolism to stimulation of breast cancer growth. Pathol Oncol Res 12: 69-72, 2006.

28. Chen C, Chang YC, Liu CL, Chang KJ and Guo IC: Leptininduced growth of human ZR-75-1 breast cancer cells is associated with up-regulation of cyclin D1 and c-Myc and down-regulation of tumor suppressor p53 and p21 (WAF1/CIP1). Breast Cancer Res Treat 98: 121-132, 2006.

29. Gonzalez RR, Cherfils S, Escobar M, Yoo JH, Carino C, Styer AK, Sullivan BT, Sakamoto H, Olawaiye A, Serikawa T, Lynch MP and Rueda BR: Leptin signaling promotes the growth of mammary tumors and increases the expression of vascular endothelial growth factor (VEGF) and its receptor type two (VEGF-R2). J Biol Chem 281: 26320-26328, 2006.

30. Leslie K, Lang C, Devgan G, Azare J, Berishaj M, Gerald W, Kim YB, Paz K, Darnell JE, Albanese C, Sakamaki T, Pestell R and Bromberg J: Cyclin D1 is transcriptionally regulated by and required for transformation by activated signal transducer and activator of transcription 3. Cancer Res 66: 2544-2552, 2006. 
31. Hsieh FC, Cheng G and Lin J: Evaluation of potential Stat3regulated genes in human breast cancer. Biochem Biophys Res Commun 335: 292-299, 2005

32. Dieudonne MN, Machinal-Quelin F, Serazin-Leroy V, Leneveu MC, Pecquery R and Giudicelli Y: Leptin mediates a proliferative response in human MCF-7 breast cancer cells. Biochem Biophys Res Commun 293: 622-628, 2002.

33. Frankenberry KA, Skinner H, Somasundar P, McFadden DW and Vona-Davis L: Leptin receptor expression and cell signaling in breast cancer. Int J Oncol 28: 985-993, 2006.

34. Wyatt SB, Winters KP and Dubbert PM: Overweight and obesity: prevalence, consequences, and causes of a growing public health problem. Am J Med Sci 331: 166-174, 2006.

35. Smigal C, Jemal A, Ward E, Cokkinides V, Smith R, Howe HL and Thun M: Trends in breast cancer by race and ethnicity: update 2006. CA Cancer J Clin 56: 168-183, 2006.

36. Parkin DM and Fernandez LM: Use of statistics to assess the global burden of breast cancer. Breast J 12 (suppl 1): S70-S80, 2006.

37. Dignam JJ and Mamounas EP: Obesity and breast cancer prognosis: an expanding body of evidence. Ann Oncol 15: 850-851, 2004.

38. Rose DP, Gilhooly EM and Nixon DW: Adverse effects of obesity on breast cancer prognosis, and the biological actions of leptin (Review). Int J Oncol 21: 1285-1292, 2002.

39. Calle EE and Thun MJ: Obesity and cancer. Oncogene 23: 6365-6378, 2004

40. Yin N, Wang D, Zhang H, Yi X, Sun X, Shi B, Wu H, Wu G, Wang $X$ and Shang Y: Molecular mechanisms involved in the growth stimulation of breast cancer cells by leptin. Cancer Res 64: 5870-5875, 2004.

41. Okumura M, Yamamoto M, Sakuma H, Kojima T, Maruyama T, Jamali M, Cooper DR and Yasuda K: Leptin and high glucose stimulate cell proliferation in MCF-7 human breast cancer cells: reciprocal involvement of PKC- $\alpha$ and PPAR expression. Biochim Biophys Acta 1592: 107-116, 2002.

42. Somasundar P, Yu AK, Vona-Davis L and McFadden DW: Differential effects of leptin on cancer in vitro. J Surg Res 113: 50-55, 2003.

43. Garofalo C, Sisci D and Surmacz E: Leptin interferes with the effects of the antiestrogen ICI 182,780 in MCF-7 breast cancer cells. Clin Cancer Res 10: 6466-6475, 2004.

44. Brueggemeier RW and Diaz-Cruz ES: Relationship between aromatase and cyclooxygenases in breast cancer: potential for new therapeutic approaches. Minerva Endocrinol 31: 13-26, 2006.

45. Mitrunen K and Hirvonen A: Molecular epidemiology of sporadic breast cancer: the role of polymorphic genes involved in oestrogen biosynthesis and metabolism. Mutat Res 544: 9-41, 2003.

46. Williams JA and Phillips DH: Mammary expression of xenobiotic metabolizing enzymes and their potential role in breast cancer. Cancer Res 60: 4667-4677, 2000.

47. Sissung TM, Price DK, Sparreboom A and Figg WD: Pharmacogenetics and regulation of human cytochrome P450 1B1: Implications in hormone-mediated tumor metabolism and a novel target for therapeutic intervention. Mol Cancer Res 4: 135-150, 2006

48. Haas S, Pierl C, Harth V, Pesch B, Rabstein S, Bruning T, Ko Y, Hamann U, Justenhoven C, Brauch H and Fischer HP: Expression of xenobiotic and steroid hormone metabolizing enzymes in human breast carcinomas. Int J Cancer 119: 1785-1791, 2006.

49. Wu J: Apoptosis and angiogenesis: two promising tumor markers in breast cancer (review). Anticancer Res 16: 2233-2239, 1996.

50. Liang Y, Brekken RA and Hyder SM: Vascular endothelial growth factor induces proliferation of breast cancer cells and inhibits the anti-proliferative activity of anti-hormones. Endocr Relat Cancer 13: 905-919, 2006.

51. Rodrigues S, Bruyneel E, Rodrigue CM, Shahin E and Gespach C: Cyclooxygenase 2 and carcinogenesis. Bull Cancer 91: S61-S76, 2004.

52. Somasundar P, McFadden DW, Hileman SM and Vona-Davis L: Leptin is a growth factor in cancer. J Surg Res 116: 337-349, 2004.

53. Ogunwobi O, Mutungi G and Beales IL: Leptin stimulates proliferation and inhibits apoptosis in Barrett's esophageal adenocarcinoma cells by cyclooxygenase-2-dependent, prostaglandin-E2-mediated transactivation of the epidermal growth factor receptor and c-Jun NH2-terminal kinase activation. Endocrinology 147: 4505-4516, 2006.
54. Sierra-Honigmann MR, Nath AK, Murakami C, Garcia-Cardena G, Papapetropoulos A, Sessa WC, Madge LA, Schechner JS, Schwabb MB, Polverini PJ and Flores-Riveros JR: Biological action of leptin as an angiogenic factor. Science 281: 1683-1686, 1998.

55. Cao R, Brakenhielm E, Wahlestedt C, Thyberg J and Cao Y: Leptin induces vascular permeability and synergistically stimulates angiogenesis with FGF-2 and VEGF. Proc Natl Acad Sci USA 98: 6390-6395, 2001.

56. Stefano R, Agostara B, Calabro M, Campisi I, Ravazzolo B, Traina A, Miele $\mathrm{M}$ and Castagnetta L: Expression levels and clinical-pathological correlations of HER2/neu in primary and metastatic human breast cancer. Ann NY Acad Sci 1028: 463-472, 2004.

57. Kepple J, Henry-Tillman RS, Klimberg VS, Layeeque R, Siegel E, Westbrook K and Korourian S: The receptor expression pattern in ductal carcinoma in situ predicts recurrence. Am J Surg 192: 68-71, 2006.

58. Uzzan B, Nicolas P, Cucherat M and Perret GY: Microvessel density as a prognostic factor in women with breast cancer: a systematic review of the literature and meta-analysis. Cancer Res 64: 2941-2955, 2004.

59. Blackwell KL, Dewhirst MW, Liotcheva V, Snyder S, Broadwater G, Bentley R, Lal A, Riggins G, Anderson S, Vredenburgh J, Proia A and Harris LN: HER-2 gene amplification correlates with higher levels of angiogenesis and lower levels of hypoxia in primary breast tumors. Clin Cancer Res 10: 4083-4088, 2004.

60. Liekens S, De Clercq E and Neyts J: Angiogenesis: Regulators and clinical applications. Biochem Pharmacol 61: 253-270, 2001.

61. Hausman GJ and Richardson RL: Adipose tissue angiogenesis. J Anim Sci 82: 925-934, 2004.

62. Folkman J: Angiogenesis and apoptosis. Semin Cancer Biol 13: 159-167, 2003.

63. Milewicz T, Krzysiek J, Janczak-Saif A, Sztefko K and Krzyczkowska-Sendrakowska M: Age, insulin, SHBG and sex steroids exert secondary influence on plasma leptin level in women. Endokrynol Pol 56: 883-890, 2005.

64. Renehan AG, Harvie M and Howell A: Insulin-like growth factor (IGF)-I, IGF binding protein-3, and breast cancer risk: eight years on. Endocr Relat Cancer 13: 273-278, 2006.

65. Jerome L, Shiry L and Leyland-Jones B: Anti-insulin-like growth factor strategies in breast cancer. Semin Oncol 31 (1 suppl 3): 54-63, 2004.

66. Shimizu C, Hasegawa T, Tani Y, Takahashi F, Takeuchi M, Watanabe T, Ando M, Katsumata N and Fujiwara Y: Expression of insulin-like growth factor 1 receptor in primary breast cancer: immunohistochemical analysis. Hum Pathol 35: 1537-1542, 2004.

67. Koda M, Przystupa W, Jarzabek K, Wincewicz A, KanczugaKoda L, Tomaszewski J, Sulkowska M, Wolczynski S and Sulkowski S: Expression of insulin-like growth factor-I receptor, estrogen receptor alpha, Bcl-2 and Bax proteins in human breast cancer. Oncol Rep 14: 93-98, 2005.

68. Shin A, Ren Z, Shu XO, Cai Q, Gao YT and Zheng W: Expression patterns of insulin-like growth factor 1 (IGF-I) and its receptor in mammary tissues and their associations with breast cancer survival. Breast Cancer Res Treat 2006.

69. Eisenberg A, Biener E, Charlier M, Krishnan RV, Djiane J, Herman B and Gertler A: Transactivation of erbB2 by short and long isoforms of leptin receptors. FEBS Lett 565: 139-142, 2004.

70. Menendez JA, Vellon L and Lupu R: Antitumoral actions of the anti-obesity drug orlistat (Xenical ${ }^{\mathrm{TM}}$ ) in breast cancer cells: blockade of cell cycle progression, promotion of apoptotic cell death and PEA3-mediated transcriptional repression of Her2/neu (erbB-2) oncogene. Ann Oncol 16: 1253-1267, 2005.

71. Cleary MP, Grande JP, Juneja SC and Maihle NJ: Diet-induced obesity and mammary tumor development in MMTV-neu female mice. Nutr Cancer 50: 174-180, 2004.

72. Coskun U, Gunel N, Toruner FB, Sancak B, Onuk E, Bayram O, Cengiz O, Yilmaz E, Elbeg S and Ozkan S: Serum leptin, prolactin and vascular endothelial growth factor (VEGF) levels in patients with breast cancer. Neoplasma 50: 41-46, 2003.

73. Sauter ER, Garofalo C, Hewett J, Hewett JE, Morelli C and Surmacz E: Leptin expression in breast nipple aspirate fluid (NAF) and serum is influenced by body mass index (BMI) but not by the presence of breast cancer. Horm Metab Res 36: 336-340, 2004.

74. Gaja A: Diurnal rhythm of serum leptin in patients with solid tumors. Vnitr Lek 50: 300-304, 2004. 
75. Stattin P, Soderberg S, Biessy C, Lenner P, Hallmans G, Kaaks R and Olsson T: Plasma leptin and breast cancer risk: A prospective study in northern Sweden. Breast Cancer Res Treat 86: 191-196, 2004.

76. Jen KLC, Buison A, Darga L and Nelson D: The relationship between blood leptin level and bone density is specific to ethnicity and menopausal status. J Lab Clin Med 146: 18-24, 2005.

77. Woo HY, Park H, Ki CS, Park YL and Bae WG: Relationships among serum leptin, leptin receptor gene polymorphisms, and breast cancer in Korea. Cancer Lett 237: 137-142, 2006.

78. Petridou E, Papadiamantis Y, Markopoulos C, Spanos E, Dessypris N and Trichopoulos D: Leptin and insulin growth factor I in relation to breast cancer (Greece). Cancer Causes Control 11: 383-388, 2000.

79. Falk RT, Brinton LA, Madigan MP, Potischman N, Sturgeon SR, Malone KE and Daling JR: Interrelationships between serum leptin, IGF-1, IGFBP3, C-peptide and prolactin and breast cancer risk in young women. Breast Cancer Res Treat 98: 157-165, 2006.

80. Mantzoros CS, Bolhke K, Moschos S and Cramer DW: Leptin in relation to carcinoma in situ of the breast: A study of premenopausal cases and controls. Int J Cancer 80: 523-526, 1999.
81. Ozet A, Arpaci F, Yilmaz MI, Ayta H, Ozturk B, Komurcu S, Yavuz AA, Tezcan Y and Acikel C: Effects of tamoxifen on the serum leptin level in patients with breast cancer. Jpn J Clin Oncol 31: 424-427, 2001.

82. Tessitore L, Vizio B, Pesola D, Cecchini F, Mussa A, Argiles JM and Benedetto C: Adipocyte expression and circulating levels of leptin increase in both gynaecological and breast cancer patients. Int J Oncol 24: 1529-1535, 2004

83. Han C, Zhang HT, Du L, Liu X, Jing J, Zhao X, Yang X and Tian D: Serum levels of leptin, insulin, and lipids in relation to breast cancer in China. Endocrine 26: 19-24, 2005.

84. Chen DC, Chung YF, Yeh YT, Chaung HC, Kuo FC, Fu OY, Chen HY, Hou MF and Yuan SSF: Serum adiponectin and leptin levels in Taiwanese breast cancer patients. Cancer Lett 237: 109-114, 2006

85. Goodwin PJ, Ennis M, Fantus IG, Pritchard KI, Trudeau ME, Koo $\mathrm{J}$ and Hood N: Is leptin a mediator of adverse prognostic effects of obesity in breast cancer? J Clin Oncol 23: 6037-6042, 2005.

86. Miyoshi Y, Funahashi T, Tanaka S, Taguchi T, Tamaki Y, Shimomura I and Noguchi S: High expression of leptin receptor mRNA in breast cancer tissue predicts poor prognosis for patients with high, but not low, serum leptin levels. Int J Cancer 118: 1414-1419, 2006 